\title{
Backbone flexibility controls the activity and specificity of a protein-protein interface- specificity in snake venom metalloproteases (SVMPs)
}

\author{
Hannes G Wallnoefer ${ }^{1}$, Torsten Lingott ${ }^{2}$, José María Gutiérrez ${ }^{3}$, Irmgard Merfort ${ }^{2}$, Klaus R Liedl ${ }^{*}$ \\ From 6th German Conference on Chemoinformatics, GCC 2010 \\ Goslar, Germany. 7-9 November 2010
}

Protein-Protein interfaces have crucial functions in many biological processes [1]. The large interaction areas of such interfaces show complex interaction motifs. Even more challenging is the understanding of (multi-)specificity in protein-protein binding. Many proteins can bind several partners to mediate their function [2].

A perfect paradigm to study such multi-specific proteinprotein interfaces are snake venom metalloproteases (SVMPs) [3]. Inherently, they bind to a variety of basement membrane proteins of capillaries, hydrolyze them, and induce profuse bleeding. However, despite having a high sequence homology, some SVMPs show a strong hemorrhagic activity, while others are (almost) inactive [4].

Our results indicate that the activity to induce hemorrhage, and thus the capability to bind the potential reaction partners, is related to the backbone flexibility in a certain surface region [4]. A subtle interplay between flexibility and rigidity of two loops seems to be the prerequisite for the proteins to carry out their damaging function. Presumably, a significant alteration in the backbone dynamics makes the difference between SVMPs that induce hemorrhage and the inactive ones.

\footnotetext{
Author details

'Institute of General, Inorganic and Theoretical Chemistry, Faculty of Chemistry and Pharmacy, University of Innsbruck, Innsbruck, 6020, Austria. ${ }^{2}$ Institute of Pharmaceutical Sciences, Department of Pharmaceutical Biology and Biotechnology, University of Freiburg, 79104 Freiburg, Germany. Instituto Clodomiro Picado, Facultad de Microbiología, Universidad de Costa Rica, San José, Costa Rica.
}

\footnotetext{
* Correspondence: klaus.liedl@uibk.ac.at

'Institute of General, Inorganic and Theoretical Chemistry, Faculty of Chemistry and Pharmacy, University of Innsbruck, Innsbruck, 6020, Austria
} Full list of author information is available at the end of the article
Published: 19 April 2011

\section{References}

1. Mandell DJ, Kortemme T: Computer-aided design of functional protein interactions. Nat Chem Biol 2009, 5:797-807

2. Han JD, Hao T, Goldberg DS, Berriz GF, Zhang LV, Dupuy D, Walhout AJM, Cusick ME, Roth FP, Vidal M: Evidence for dynamically organized modularity in the yeast protein-protein interaction network. Nature 2004, 430:88-93

3. Bjarnason JB, Fox JW: Hemorrhagic metalloproteinases from snake venoms. Pharmac Ther 1994, 62:325-372.

4. Wallnoefer HG, Lingott T, Gutiérrez JM, Merfort I, Liedl KR: Backbone Flexibility Controls the Activity and Specificity of a Protein - Protein Interface: Specificity in Snake Venom Metalloproteases. J Am Chem Soc 2010, 132:10330-10337.

doi:10.1186/1758-2946-3-S1-O22

Cite this article as: Wallnoefer et al:: Backbone flexibility controls the activity and specificity of a protein-protein interface-specificity in snake venom metalloproteases (SVMPs). Journal of Cheminformatics 20113 (Suppl 1):O22.
Publish with ChemistryCentral and every scientist can read your work free of charge

“Open access provides opportunities to our colleagues in other parts of the globe, by allowing anyone to view the content free of charge."

W. Jeffery Hurst, The Hershey Company.

- available free of charge to the entire scientific community

- peer reviewed and published immediately upon acceptance

- cited in PubMed and archived on PubMed Central

- yours - you keep the copyright

Submit your manuscript here:

http://www.chemistrycentral.com/manuscript/ 